\title{
The Effect of Learning Method on Economic Learning Outcome of High School Students in Bima
}

\author{
Yendi $^{1}$, Djoko Santoso ${ }^{1}$, Tri Murwaningsih ${ }^{1}$ \\ ${ }^{1}$ Faculty of Teacher Training and Education, Universitas Sebelas Maret, Indonesia \\ email: yendibima@gmail.com
}

\begin{abstract}
This research aimed to determine the effect of teaching method toward learning result of students in Economics class XI social Sciences at SMA Negeri 2 Wera and SMA Negeri 3 Wera distric Bima Nusa Tenggara Barat. The method used in this study, using descriptive quantitative. The method used in this study, using descriptive quantitative. The result showed that the analysis testing the effectiveness of method with t-test formula and score of t-observes were obtained from the questionnaire and the score of students were 9.768 with t-table score 1.664 . Then $t-$ observes were higher than t-table. It means that there was significant interaction effect between learning method toward learning outcomes. From those results, it can be concluded that there was a significant and positive effect from learning method toward students learning outcomes in econimic. Based on the description can be ascertained that the application of varied learning methods will be able to foster high learning motivation so that this will be able to improve student learning outcomes.
\end{abstract}

\section{Keywords: Method;Learning Outcomes; Teaching Method}

\section{INTRODUCTION}

Education is a very important aspect in human life, because it is capable of forming skilled human resources. For such purposes the educator should be able to make the process of learning that happens to be a process that will increase the learner's personality. Educators charged with full awareness to design instructional activities systematically through the utilization of all existing facilities, which can improve the learning results of students in achieving the target instruction. Many factors can influence learning outcomes students such as facilities and infrastructure that are in school and at home so that the learners how to learn is not the maximum. On the other hand the use of a less varied method or not varies so that participants will be passive in the face of the learning process and less interested in studying economic subjects.

In that case, these educators have a central role in carrying out the process of learning to the learners. Thus educators must be able to create an atmosphere conducive to learning that can guide learners are active and creative in giving questions. Because the learning process for students require many things, including giving the opportunity to learners for mengampaikan opinions directly. One way prepared in preparing learners who are learning method using quality varies. 
"increasing the learning achievements of students on the subject of integers and solving the problem of the use of the varied methods (methods lectures, q \&amp; a, discussion, and the granting of duty), because it can evoke the liveliness of the learners in responding to the lessons presented and the courage of the learners in answering the question can be enhanced through filing questions short and clear, and the giving time to the learners to think in solving a problem is given" [14]. The use of lecture methods varies with question and answer method, assignment, demonstration and some other methods adapted to conductive situation and condition [11]. Effective methods used by educators in teaching environmental education successively are lecture methods, direct experience methods and discussion methods [1]. The existence of educators in teaching and learning activities greatly determine the quality of learners. Educators don't merely conveying a material but rather to give educators the freedom to develop his knowledge of learners through discussions of the problems examined collectively, by asking a question or answer oral or writing against the learning material so that students participate actively in the teaching and learning activities

Educators not only serves as a facilitator. But educators should be able to develop creative thinking and acting students that will increase the results of the study. Just as in the learning process of economic subjects. One of the steps to have a strategymust master presentation techniques in learning or methods used in the study. The most traditional way of teaching used in the history of education is how to teach using the cerama. The method is a method of lecture delivered by an educator againsta verbal learners.

When an educator at school only convey the theory by using the method of lecture and less opportunity to learners for menggalih a problem and mengampaikan an opinion or question so that the learners also participated actively in the classroom. Educators only treating learners as active listeners and noted what the explanations and writings of educators on the Board. The use of methods lectures should be supported by other methods such as the method of discussion, faqs and training for educators when giving a talk it is necessary to hold a question and answer in the learning process. The necessity of this question and answer to find out the extent to which learners will understand the material presented by educators via the methods employed educators on economic subjects. Various methods of learning that created educators as a solution in the learning process so that learning can be.

The method is the steps undertaken educators to understand the capabilities of the learners, the method is a series of specific measures and ways of realizing the pattern remains [5]. The method is a technique in science and technology class is making the experiment. This is followed by lectures, notes, projects, group work, puzzle, playdrama and trip-observation, respectively [2]. Teaching methods is the way used by educators in holding relationships with students at the time of the process of teaching and learning [16]. The method is like an umbrella of inter-relationships of a specific theory and practice [2].

Based on the observation field in SMAN 2 Wera and SMAN 3 Wera using methods vary in their learning process, namely the method of lecture, discussion, faqs and the granting of delegated tasks. The results of the initial interview research proves the fact that there are problems in economic studies that occur at school, for researchers conducting research early in the school, there are a lot of complaints from the pupils. The decrease was mainly the result of learning students due to the 
in-school educators are still widely use methods lectures, many feel the learning process quite boring, students assume the current education less provides for freedom of thought, so that learners passive and less vibrant. It is becoming less attractive to learners so that the learning motivation of learners increased less. In this case will affect the results of the learning learners.

\section{Types of learning methods}

1. Methods lectures

Methods lectures is the traditional method used as oral communication tool amongeducators and learners [4].

2. Discussion Method

Discussion is a process where two or more persons, clarify and reveal their pool of knowledge, experience, opinions, and feelings [13].

3. Question and answer method

Question and answer method is a method which makes the onset of interaction educators and learners are active [7].

4. The Method Of Granting

The method of granting is a teaching method applied in the teaching and learningprocess, commonly referred to by the method of granting

The method is the work done by educators in order to understand the behavior of the target learners of science that it may get the learning objectives that are alreadyspecified in the instruction.

\section{RESEARCH METHODS}

The research used in this research is quantitative descriptive in nature with the approach of the survey. According to my research it is easy so will speed up the processof research, but it's not that easy though this research was conducted with random,thus able to obtain maximum results and good, because this research terjung directly to take samples from a population that is already determined. A population or sample in this research totalled 84 people learners. This research was carried out in SMA Negeri 2 Wera and SMA Negeri 3 Wera distric bima nusa tenggara province and implementation time starting from the month of February until April 2017. Data collection techniques using question form, documentation and interviews. Technique of data analysis using t-test.

\section{RESULTS AND DISCUSSION}

This research was done at the class XI economic subjects in SMA Negeri 2 Wera and SMA Negeri 3 Wera distric Bima Nusa Tenggara Province with samples as many as 84 people learners.

Before the collection of data about the results of the study carried out, terlebi first data instruments tested cobakan to learners outside the sample to find out the validity and reliability of the instrument. This instrument tests done to learners SMA Negeri 1 Wera distric Bima Nusa Tenggara Province that add up to 20 learners have 
characteristics that are not much different from learners who will become the respondents in this study. Trial results showed learning methods questionnaire instrument which is valid and reliability with kriterial testing is t-observes was higher than t-table. The following details the results of the data processing has been done with the help of the program SPSS version 18 for windows.

\section{Learning Methods}

The method is the steps undertaken educators to understand the capabilities of the learners.

To know the limits of interval used the formula by comparing the average priceof the respondent's answer or question results question form a scale value of the respondent's answer or question question form the scale value as follows:

$$
\text { Interval }=\frac{\text { The highest value }- \text { the lowest value }}{\text { Interval distance }}
$$

Based on the formula, then the result is:

$$
\text { Interval }=\frac{4-1}{4}=0.75
$$

Based on the results of the above calculation, then retrieved the boundary interval that is of 0.75 and categorized as follows:

TABLE I. LIMIT INTERVAL

\begin{tabular}{|c|c|}
\hline Interval & Category \\
\hline $1.00-1.75$ & Not Good \\
\hline $1.76-2.50$ & Less Good \\
\hline $2.51-3.25$ & Good \\
\hline $3.26-4.00$ & Very Good \\
\hline
\end{tabular}

Next, to find out the description of the method of learning $(\mathrm{X})$ learners economic subjects can be seen from the tables tabulate the frequency and percentage of respondent's answers brought:

TABLE II. FREQUENCY DISTRIBUTION LEARNING METHODS LEARNERS ECONOMIC

\begin{tabular}{|c|c|c|c|c|c|c|c|c|c|c|c|}
\hline \multirow{3}{*}{$\begin{array}{c}\text { No } \\
\text { Item }\end{array}$} & \multicolumn{8}{|c|}{ Answer Options } & \multirow{2}{*}{\multicolumn{2}{|c|}{ amount }} & \multirow{3}{*}{ Average } \\
\hline & \multicolumn{2}{|c|}{ VG $=4$} & \multicolumn{2}{|c|}{$\mathbf{G}=\mathbf{3}$} & \multicolumn{2}{|c|}{$\mathbf{N G}=2$} & \multicolumn{2}{|c|}{$\mathrm{NVG}=1$} & & & \\
\hline & $\mathbf{F}$ & $\mathbf{S C}$ & $\mathbf{F}$ & $\mathbf{S C}$ & $\mathbf{F}$ & $\overline{\mathbf{S C}}$ & $\mathbf{F}$ & SC & $\mathbf{F}$ & SC & \\
\hline 1 & 35 & 140 & 45 & 135 & 4 & 8 & 0 & 0 & 84 & 283 & 3.36 \\
\hline 2 & 32 & 128 & 40 & 120 & 12 & 24 & 0 & 0 & 84 & 272 & 3.24 \\
\hline 3 & 34 & 136 & 40 & 120 & 10 & 20 & 0 & 0 & 84 & 276 & 3.28 \\
\hline 4 & 37 & 148 & 38 & 114 & 9 & 18 & 0 & 0 & 84 & 280 & 3.33 \\
\hline 5 & 43 & 172 & 30 & 90 & 11 & 22 & 0 & 0 & 84 & 284 & 3.38 \\
\hline 6 & 33 & 132 & 35 & 105 & 16 & 32 & 0 & 0 & 84 & 269 & 3.20 \\
\hline 7 & 42 & 168 & 28 & 84 & 13 & 26 & 1 & 1 & 84 & 279 & 3.32 \\
\hline 8 & 42 & 168 & 36 & 108 & 6 & 12 & 0 & 0 & 84 & 288 & 3.43 \\
\hline 9 & 40 & 160 & 34 & 102 & 10 & 20 & 0 & 0 & 84 & 282 & 3.36 \\
\hline
\end{tabular}
SUBJECT 
Table II, cont.

\begin{tabular}{|r|c|c|c|c|c|c|c|c|c|c|r|}
\hline $\mathbf{1 0}$ & 33 & 132 & 34 & 102 & 17 & 34 & 0 & 0 & 84 & 268 & 3.2 \\
\hline $\mathbf{1 1}$ & 31 & 124 & 42 & 126 & 11 & 22 & 0 & 0 & 84 & 272 & 3.24 \\
\hline $\mathbf{1 2}$ & 18 & 72 & 17 & 51 & 27 & 54 & 22 & 22 & 84 & 199 & 2.37 \\
\hline $\mathbf{1 3}$ & 39 & 156 & 33 & 99 & 12 & 24 & 0 & 0 & 84 & 279 & 3.32 \\
\hline $\mathbf{1 4}$ & 39 & 156 & 23 & 69 & 21 & 42 & 1 & 1 & 84 & 268 & 3.2 \\
\hline $\mathbf{1 5}$ & 43 & 172 & 31 & 93 & 10 & 20 & 0 & 0 & 84 & 285 & 3.4 \\
\hline $\mathbf{1 6}$ & 19 & 76 & 30 & 90 & 25 & 50 & 10 & 10 & 84 & 226 & 2.7 \\
\hline $\mathbf{1 7}$ & 45 & 180 & 30 & 90 & 8 & 16 & 1 & 1 & 84 & 287 & 3.42 \\
\hline \multicolumn{10}{|c|}{ Average } \\
\hline
\end{tabular}

Information :

$\mathrm{F} \quad=$ Frequency of Answer

$\mathrm{SC} \quad=$ Frequency $\mathrm{X}$ Answer Value

Of the total value of all results of the answers of respondents regarding learning methods retrieved the value of the overall 54.75 with average value 3.22 and includes both categories.

\section{The Results Of The Learning Learners}

The results of the study was the ability of learners when finished doing the teaching and learning activities that are defined by educators in accordance with contribution given in instruction. The value of learning to students majoring in SOCIAL SCIENCE subjects of economic diperoles of the UAS (final exams of the Semester).

The following is a calculation of the range of economic subjects, learning outcomes:

TABLE III. CALCULATION OF RESULTS RANGE OF LEARNING ECONOMICS SUBJECT.

\begin{tabular}{|c|c|}
\hline Span & Category \\
\hline $90-100$ & Very Good \\
\hline $80-89$ & Good \\
\hline $70-79$ & Enough \\
\hline $0-69$ & Not Pass \\
\hline
\end{tabular}

Based on the above table can be seen the scale of the value of learning results obtained by learners economic subjects as can be seen in Table IV.

Based on the data about the results of the economic study participants noted that the average value of the respondents amounted to 81.54. Thus the results of the study of economics students categorized either.

TABLE IV. RATING SCALE OF LEARNING RESULTS OF ECONOMICS SUBJECT.

\begin{tabular}{|c|c|c|}
\hline Span & Category & F \\
\hline $90-100$ & Very Good & 16 \\
\hline $80-89$ & Good & 45 \\
\hline $70-79$ & Enough & 23 \\
\hline $0-69$ & Not Pass & - \\
\hline & Amount & 84 \\
\hline
\end{tabular}




\section{Data Analysis Techniques}

To test the hypothesis that the variable of learning method partially influence the learning result, then t test is used. Hypothesis testing is done by comparing the value of t-observer with t-table and compare the significant level (Sig) of research with alpha $(\alpha)$ level of 0.05 . The value of t-observing for variables and constants can be seen in the table below:

TABLE V. CALCULATION RESULT T TEST VARIABLE X WITH Y COEFFICIENTS ${ }^{\mathrm{A}}$

\begin{tabular}{|l|r|r|r|r|r|}
\hline \multirow{2}{*}{ Model } & \multicolumn{2}{|c|}{$\begin{array}{c}\text { Unstandardized } \\
\text { Coefficients }\end{array}$} & $\begin{array}{c}\text { Standardized } \\
\text { Coefficients }\end{array}$ & & \\
\cline { 2 - 5 } & \multicolumn{1}{|c|}{$\mathrm{B}$} & \multicolumn{1}{c|}{$\begin{array}{c}\text { Std. } \\
\text { Error }\end{array}$} & Beta & \multicolumn{1}{c|}{ T } & \multicolumn{1}{c|}{ Sig. } \\
\hline (Constant) & 33.031 & 4.989 & & 6.620 & .000 \\
Learning methods & .891 & .091 & .733 & 9.768 & .000 \\
\hline
\end{tabular}

a. Dependent Variable: learning outcomes

Based on the results of the above table it can be seen that for the variable of learning method $(\mathrm{X})$ obtained $\mathrm{t}$-observe value of $=9.768$ and when distributed at a significant level of $95 \%$ or $=5 \%$ obtained ttable of $=1.664$. So $(9.768>1.664)$. Learning method variable $(\mathrm{X})$ obtained sig of 0.000 and $\alpha$ equal to 0.05 . So that sig $<\alpha(0.000<0.05)$ with degree of trust $95 \%$. Thus, the hypothesis states that there is a positive and significant influence between the learning method $(\mathrm{X})$ on learning outcomes (Y). This means that the variable of learning method (X) has a positive and partially significant influence on learning outcomes (Y).

\section{CONCLUSIONS AND IMPLICATIONS}

Based on the results of testing and discussion of the results of research that has been collected on the influence of learning methods on student learning outcomes subjects economy class XI in SMA Negeri 2 Wera and SMA Negeri 3 Wera Bima NTB, Then obtained the results of hypothesis testing using t test of 9.768 with t-table value of 1.664 thus t-observe larger than t-table, it shows "There is a positive and significant influence between the learning method on the students' learning outcomes of economic subjects of class XI in SMA Negeri 2 Wera and SMA Negeri 3 Wera distric Bima NTB".

This study proves that the competence of economic learning will be improved by the application of varied learning methods. Selection of appropriate learning methods will greatly help learners in facilitating the understanding of learners about the subject matter delivered by educators. With the proper presentation of teaching methods used adapted to the material presented will be able to attract the attention of learners to deepen the material presented by educators.

Based on the above description can be ascertained that the application of varied learning methods will be able to grow high learning motivation learners so that this will be able to improve student learning outcomes. 


\section{REFERENCES}

[1] Aida, N dan Rini, P.A. (2015). Application of Role Playing Methods to Improve Socializing Skills in Early Childhood Education.. Journal Psychology Indonesia. 4, (01) 87 - 99.

[2] Akinoglu, O. (2008). Assessment Of The Inquiry-Based Project Implementation Process In Science Education Upon Students' Points Of Views. International Journal Of Instruction, 1 (1) $1-12$.

[3] Arikunto, S. (2006). Research Procedures A Practice Approach. Jakarta : Rineka Cipta

[4] Djamarah, B.S. (2005). Teachers and students in interactive educative. Jakarta: Rineka Cipta

[5] Ediyono, S. (2014). Science phylosophy. Yogyakarta: Kaliwangi

[6] Hamid, S.M. (2012). Edu Taiment Method. Yogyakarta: DIVA Press

[7] Kamelia, Firmansyah, A dan Dewi I.A. (2013). Improving Student Learning Outcomes through Question and Answer Methods. Creative Journal of Tadulako Online. 5 (7) 147-160.

[8] Miseng, A. (2015). Improving Student Motivation with Applied Guided Exercise Using Point System In Economics Subject. Journal of Educational Reason. 3 (1) 261-269

[9] Merlyn, M.R and Abratt P.C. (2011). Storytelling in reputation management: the case of Nashua Mobile South Africa. Journal Of Management Decision. 49 (3) 405 - 421

[10] Muslicha Anisa. (2015). Teaching Method In Environmental Education In Primary School Students (Study At Adiwiyata School in DKI Jakarta). Educational journal. 16 (2) 110-126.

[11] Novita Resmi. (2014). The effectiveness of the use of lecture methods varies in improving multiplication operations for children with learning difficulties. E-JUPKhu (Journal of special education). Http://ejournal.unp.ac.id/index.php/jupekhu. 192-204 JOURNAL

[12] Rafli, Z dan Lustyantie, N. (2016). Language Learning Theory. Yogyakarta: Garudhawaca

[13] Rahman, F., Jaddi, K.K., Nabi, B.J., Muhammad, A., Samina, dan Muhammad, S. (2011). Impact of Discussion Method on Students Performance. International Journal of Business and Social Science. 2 (7) 84-94

[14] Rahmi, U (2009). Variable Methods Can Increase Student Achievement Learning Mathematics Grade V SDN I Olo-Oloho District Pakue District North Kolaka. Journal of PMIPA / Matematica FKIP Unhalu Bumi Tridharma Kendari Campus. 8 (1) 18-27.

[15] Sugiyono. (2013). Combination Research Methods (Mixed Methods). Bandung: Alfabeta.

[16] Sumarni, Abduh, H.H dan Imran (2016). Application of Discussion Methods to Improve Student Learning Outcomes. Creative Journal of Tadulako Online. 3 (4) 13-22.

[17] Sutriani., Barra, M., Tandiayuk dan Paloloang, B. (2013). Application of Assignment Methods to Improve Learning Outcomes in Addition and Fractional Substance Content. Journal Creativity Tadulako Online University Tadulako Sulawesi. 4 (1) 18-3 